Vol. VII No. 1, April 2014

P.ISSN: 1979-858X

Halaman $15-25$

\title{
PENGARUH PARTISIPASI PENGANGGARAN, KEADILAN PROSEDURAL, DAN GAYA KEPEMIMPINAN TERHADAP KOMITMEN ORGANISASI
}

\author{
Nur Dian Fitriana \\ Soliyah Wulandari \\ Yahya Hamzah \\ UIN Syarif Hidayatullah Jakarta
}

\begin{abstract}
This study describes the influence of budgetary partisipation, procedural justice, and leadership style on organizational commitment. Sample of this research obtained from employee in hospitals and clinics in South of Tangerang. Final samples are 109 respondents. Respondents in this study were employees, because they can assess the variables of budget participation, procedural fairness, and with good leadership style based on experiences during their daily work. This study is limited to employees who work in hospitals and clinics in the region of South Tangerang. Methods of sample selection is done by simple random sampling. Data analysis was perfomed using multiple regressions. Results of this research provide empirical support for budgetary participation, procedural justice, and leadership style on organizational commitment. Partisipasi penganggaran, Keadilan procedural, dan Gaya kepemimpinan memiliki pengaruh terhadap komitmen organisasi.
\end{abstract}

Keywords: Budgetary Participation, Procedural Justice, Leadership Style, Organizational Commitment.

ABSTRAK : Penelitian ini menjelaskan pengaruh partisipasi anggaran, keadilan prosedural, dan gaya kepemimpinan terhadap komitmen organisasi. Sampel penelitian ini yaitu 109 responden dari karyawan di rumah sakit dan klinik di Tangerang Selatan. esponden dalam penelitian ini adalah karyawan, karena mereka yang dapat menilai variabel partisipasi anggaran, keadilan prosedural, dan gaya kepemimpinan dengan baik berdasarkan pengalaman sehari-hari mereka selama bekerja. Penelitian ini dibatasi dengan karyawan yang bekerja di Rumah Sakit dan Klinik di wilayah Tangerang Selatan. Metode pemilihan sampel dilakukan dengan simple random sampling. DAnalisis data menggunakan regresi berganda. Hasil penelitian ini memberikan dukungan empiris untuk partisipasi anggaran, keadilan prosedural, dan gaya kepemimpinan terhadap komitmen organisasi. Partisipasi penganggaran, Keadilan procedural, dan Gaya kepemimpinan memiliki pengaruh terhadap komitmen organisasi.

Kata kunci: Partisipasi Anggaran, Keadilan Prosedural, Gaya Kepemimpinan, Komitmen Organisasi

\footnotetext{
*Draft pertama: 19 Januari 2014; Revisi: 19 Februari 2014; Diterima: 22 Maret 2014

Penulis dapat dikontak melalui: nur.dian@yahoo.com
} 


\section{PENDAHULUAN}

Setiap entitas atau organisasi tentunya didirikan oleh orang-orang yang memiliki tujuan yang sama, dan setiap orang atau karyawan yang bekerja untuk entitas tersebut hendaknya memiliki komitmen untuk bersama-sama mencapai tujuan tersebut. Komitmen yang dimiliki oleh orang-orang tersebut yang akan menjadikan kinerja mereka bertambah baik sehingga kelangsungan hidup entitas berjalan dengan baik.

Namun, pada kenyataannya banyak entitas yang di dalamnya terdapat orang-orang yang memiliki komitmen organisasi yang rendah atau bahkan tidak memilikinya. Menurut Koesmono (2007), komitmen organisasi adalah suatu keadaan dimana seorang karyawan memihak pada suatu organisasi tertentu dan tujuan-tujuannya serta berniat memelihara keanggotaan dalam organisasi. Pada karyawan yang memiliki komitmen yang rendah akan merasa tidak kerasan pada entitas atau organisasi tersebut sehingga mempengaruhi kinerja yang pada akhirnya mempengaruhi kelangsungan hidup entitas.

Banyak faktor yang dapat menimbulkan kurangnya komitmen para karyawan maupun para petinggi entitas, baik itu faktor internal maupun eksternal. Inilah yang menjadikan suatu entitas tidak berjalan dengan baik, bahkan mengalami kebangkrutan.

Dalam menjalankan suatu usaha, sebuah entitas atau organisasi tentunya memiliki fungsi manajemen untuk kelangsungan usahanya dan memiliki berbagai bentuk pengendalian. Pengendalian tersebut digunakan untuk memperkecil terjadinya berbagai macam risiko yang mungkin terjadi di masa mendatang. Dengan membuat rencana untuk masa depan, manajer belajar mengantisipasi masalah-masalah yang potensial terjadi dan cara menghadapinya. Alat akuntansi yang umum digunakan untuk mewujudkan hal tersebut adalah anggaran.

Anggaran memberikan ukuran atas hasil-hasil keuangan yang diharapkan entitas dari aktivitas-aktivitas yang direncanakan (Horngren et al., 20o8). Dalam perencanaan strategis entitas, penyusunan anggaran merupakan salah satu hal yang paling penting. Oleh karena itu, bawahan sebaiknya diikutsertakan langsung dalam proses penyusunan anggaran tersebut. Hal ini dinamakan dengan partisipasi penganggaran. Partisipasi penganggaran ini diperlukan karena bawahan yang lebih mengetahui kondisi langsung bagiannya (Fitri, 2004).

Setiap entitas seharusnya memperhatikan kebutuhan dan keadilan dalam penilaian terhadap kinerja karyawannya sehingga menimbulkan kenyamanan bekerja. Oleh karena itu, keadilan organisasi perlu ditegakkan. Menurut Ivancevich et al. (2007), konsep keadilan organisasi, yaitu tingkatan dimana individu merasa diperlakukan secara adil di tempat kerja, menarik perhatian para peneliti. Keadilan organisasi dibagi menjadi tiga, yaitu keadilan distributif, keadilan prosedural, dan keadilan interaksional (Bakhshi et al., 2009).

Keadilan prosedural merujuk pada keadilan yang dipersepsikan mengenai proses dan prosedur organisasi yang digunakan untuk membuat keputusan alokasi dan sumber daya (Ivancevich et al., 2007). Keberhasilan dalam mengelola suatu organisasi tidak lepas dari faktor kepemimpinan dan sikap bawahan dalam melaksanakan tugas mencapai tujuan organisasi (Nor, 2007). Berbagai gaya kepemimpinan akan mewarnai perilaku seorang pemimpin dalam menjalankan tugasnya. Tipe-tipe kepemimpinan ini dapat mempengaruhi komitmen organisasi yang tercipta di dalam organisasi tersebut. Menurut Koesmono (2007) komitmen organisasi merupakan identifikasi seorang individu terhadap organisasi dan tujuan-tujuannya serta berniat mempertahankan keanggotaannya.

Hasil penelitian sebelumnya mengenai pengaruh partisipasi penganggaran terhadap komitmen organisasi yang dilakukan oleh Greenberg dan Folger (1983) dalam Wasisto dan Sholihin (2004) menunjukkan bahwa partisipasi penganggaran dapat meningkatkan kinerja karena partisipasi penganggaran dapat memungkinkan bawahan untuk memilih, dan tindakan memilih tersebut dapat membangun komitmen dan dianggap sebagai tanggung 
jawab atas apa yang telah dipilih. Beberapa penelitian seperti Alutto dan Acito (1974) maupun Patchen (1965) dalam Fitri (2004) menunjukkan bahwa partisipasi penganggaran dapat meningkatkan komitmen organisasi. Nouri dan Parker (1996) dalam Abbas (2008) mengungkapkan bahwa organisasi yang berusaha menjadi lebih partisipatif memungkinkan mendapatkan komitmen organisasi dari pekerjanya. Hasil penelitian yang dilakukan oleh Abbas (2008) menunjukkan bahwa penganggaran partisipatif mempunyai pengaruh terhadap komitmen organisasi. Selain itu, penelitian yang dilakukan oleh Yunita (2009) menunjukkan bahwa partisipasi penganggaran berpengaruh positif terhadap komitmen organisasi.

Hasil penelitian sebelumnya mengenai pengaruh keadilan prosedural terhadap komitmen organisasi yang dilakukan oleh Bakhshi et al. (2009) menunjukkan bahwa keadilan prosedural memiliki hubungan terhadap komitmen organisasi. Bakhshi et al. (2009) menyatakan bahwa karyawan yang merasa diperlakukan secara adil oleh entitasnya cenderung untuk mengembangkan dan memelihara hubungan komunal dengan perusahaan, selain itu mereka kemungkinan besar memiliki lebih banyak komitmen, kepercayaan, dan kepuasan dibandingkan ketika mereka merasa diperlakukan tidak adil.

Hasil penelitian sebelumnya mengenai pengaruh gaya kepemimpinan terhadap komitmen organisasi yang dilakukan oleh Tatlah et al. (2011) menunjukkan bahwa gaya kepemimpinan memiliki pengaruh terhadap komitmen organisasi. Beberapa peneliti seperti Bateman dan Strasser (1984), Decotiis dan Summers (1987), Mathieu dan Zajac (1990) dalam Sabir et al. (2011) mengatakan bahwa terdapat hubungan yang kuat dan positif antara gaya kepemimpinan dengan komitmen organisasi. Penelitian yang dilakukan oleh Sabir et al. (2011) menunjukkan bahwa gaya kepemimpinan memiliki hubungan positif dengan komitmen organisasi. Selain itu, penelitian yang dilakukan oleh Koesmono (2007) menunjukkan bahwa kepemimpinan berpengaruh positif terhadap komitmen organisasi.

\section{KERANGKA TEORI DAN PENGEMBANGAN HIPOTESIS Komitmen Organisasi}

Menurut Sardjito dan Muthaher (2007), komitmen organisasi adalah komitmen yang menunjukan keyakinan dan dukungan yang kuat terhadap nilai dan sasaran (goal) yang ingin dicapai oleh organisasi. Selanjutnya Robbins dan Judge (2008) mendefinisikan komitmen organisasi sebagai suatu keadaan dimana seorang karyawan memihak organisasi tertentu dan tujuan-tujuannya serta berkeinginan untuk mempertahankan keanggotaan dalam organisasi tersebut. Jadi, keterlibatan pekerjaan yang tinggi berarti memihak pada pekerjaan tertentu seorang individu, sementara komitmen organisasi yang tinggi berarti memihak organisasi yang merekrut individu tersebut.

\section{Partisipasi Penganggaran}

Partisipasi pengganggaran adalah keterlibatan individu-individu dalam proses penyusunan anggaran dan mempunyai pengaruh terhadap target anggaran dan perlunya penghargaan atas pencapaian target anggaran tersebut (Brownell, 1982 dalam Falikhatun, 2007). Menurut Sardjito dan Muthaher (2007), partisipasi penganggaran yaitu tingkat seberapa jauh keterlibatan dan pengaruh individu dalam menentukan dan menyusun anggaran yang ada dalam divisi atau bagiannya, baik secara periodik maupun tahunan.

Menurut Sardjito dan Muthaher (2007), komitmen organisasi adalah komitmen yang menunjukan keyakinan dan dukungan yang kuat terhadap nilai dan sasaran (goal) yang ingin dicapai oleh organisasi. Selanjutnya Robbins dan Judge (2008) mendefinisikan

komitmen organisasi sebagai suatu keadaan dimana seorang karyawan memihak organisasi tertentu dan tujuan-tujuannya serta berkeinginan untuk mempertahankan keanggotaan dalam organisasi tersebut. 


\section{Keadilan Prosedural}

Menurut Ivancevich et al. (2007), keadilan prosedural adalah pertimbangan yang dibuat oleh karyawan mengenai keadilan yang dipersepsikan mengenai proses yang digunakan oleh organisasi untuk tiba pada keputusan seperti siapa yang menerima promosi, berapa kenaikan gaji yang akan diberikan, dan bagaimana pembayaran bonus akan dialokasikan. Masalah keadilan di tempat kerja perlu mendapatkan perhatian karena hal ini sering diabaikan, atau bahkan dilanggar pada waktu orang membiarkan diskriminasi terjadi di lingkungan perusahaan.

\section{Gaya Kepemimpinan}

Menurut Yaverbaum dan Sherman (2008), kepemimpinan adalah tindakan mendapatkan kerja sama dari orang untuk mencapai suatu tujuan. Kepemimpinan menurut Ivancevich et al. (2007) adalah proses mempengaruhi orang lain untuk mendukung pencapaian tujuan organisasi yang relevan.

\section{Pengaruh Partisipasi Penganggaran terhadap Komitmen Organisasi}

Partisipasi pengganggaran adalah keterlibatan individu-individu dalam proses penyusunan anggaran dan mempunyai pengaruh terhadap target anggaran dan perlunya penghargaan atas pencapaian target anggaran tersebut (Brownell, 1982 dalam Falikhatun, 2007). Penelitian yang dilakukan oleh Abbas (2008) mengenai pengaruh langsung dan tidak lansung partisipasi penganggaran terhadap komitmen organisasi, job relevant information, dan kinerja manajerial yang menggunakan sampel industri perhotelan di Surabaya menunjukkan bahwa partisipasi penganggaran memiliki pengaruh terhadap komitmen organisasi. Selain itu, penelitian yang dilakukan oleh Yunita (2009) mengenai pengaruh partisipasi anggaran terhadap kinerja manajerial dengan komitmen tujuan sebagai variabel intervening yang menggunakan sampel rumah sakit di Jawa Tengah dan Daerah Istimewa Yogyakarta menunjukkan bahwa partisipasi penganggaran berpengaruh positif terhadap komitmen organisasi.

Menurut penelitian yang dilakukan Greenberg dan Folger (1983) dalam Wasisto dan Sholihin (2004), partisipasi penganggaran dapat meningkatkan kinerja karena pastisipasi penganggaran memungkinkan bawahan mengkomunikasikan apa yang mereka butuhkan kepada atasannya serta dapat memungkinkan bawahan untuk memilih, dan tindakan memilih tersebut dapat membangun komitmen dan dianggap sebagai tanggung jawab atas apa yang telah dipilih.

Penelitian yang dilakukan oleh Alutto dan Acito (1974) dalam Fitri (2004) menunjukkan bahwa partisipasi karyawan dapat meningkatkan komitmen organisasi. Penelitian yang dilakukan oleh Nouri dan Parker (1996) dalam Abbas (2008) juga menunjukkan bahwa organisasi yang berusaha menjadi lebih partisipatif, memungkinkan mendapatkan komitmen organisasi dari pekerjanya.

Berdasarkan hasil penelitian tersebut, partisipasi penganggaran diduga dapat membuat karyawan merasa dianggap keberadaannya karena mereka dapat berkontribusi dalam penyusunan anggaran organisasi tempat mereka bekerja dengan menyampaikan pendapatnya dalam proses penyusunan anggaran sehingga mereka merasa menjadi bagian dari organisasi tersebut. Dengan demikian, para karyawan merasa dirinya bermanfaat atau dibutuhkan organisasi sehingga dapat mempengaruhi komitmennya terhadap organisasi. Berdasarkan hal tersebut, maka disusunlah hipotesis sebagai berikut:

$\mathbf{H}_{\mathbf{1}}$ : Partisipasi penganggaran berpengaruh terhadap komitmen organisasi. 


\section{Pengaruh Keadilan Prosedural terhadap Komitmen Organisasi}

Keadilan prosedural adalah pertimbangan yang dibuat oleh karyawan mengenai keadilan yang dipersepsikan mengenai proses yang digunakan oleh organisasi untuk tiba pada keputusan seperti siapa yang menerima promosi, berapa kenaikan gaji yang akan diberikan, dan bagaimana pembayaran bonus akan dialokasikan (Ivancevich et al., 2007). Penelitian yang dilakukan oleh Bakhshi et al. (2009) mengenai hubungan antara persepsi keadilan organisasi, kepuasan kerja, dan komitmen organisasi yang menggunakan sampel karyawan pada sekolah kesehatan menunjukkan bahwa terdapat hubungan yang signifikan antara keadilan prosedural dengan komitmen organisasi.

Keadilan prosedural berhubungan dengan persepsi bawahan mengenai seluruh proses yang diterapkan oleh atasan mereka untuk mengevaluasi kinerja mereka, sebagai sarana untuk mengkomunikasikan feedback kinerja dan untuk menentukan reward bagi mereka seperti promosi atau kenaikan gaji (McFarlin dan Sweeny, 1992 dalam Wasisto dan Sholihin, 2004). Karyawan yang merasa diperlakukan secara adil oleh entitasnya cenderung untuk mengembangkan dan memelihara hubungan komunal dengan perusahaan, selain itu mereka kemungkinan besar memiliki lebih banyak komitmen, kepercayaan, dan kepuasan dibandingkan ketika mereka merasa diperlakukan tidak adil (Bakhshi et al., 2009). Dengan diterapkannya prosedur penilaian yang adil, seperti prosedur pemberian bonus, penilaian kinerja, promosi jabatan, dan sebagainya, akan menimbulkan perasaan diperhatikan bagi para karyawan karena mereka merasa bahwa kinerja mereka selama ini dihargai dengan baik. Oleh karena itu, hipotesis dalam penelitian ini dirumuskan sebagai berikut:

$\mathbf{H}_{2}$ : Keadilan prosedural berpengaruh terhadap komitmen organisasi.

\section{Pengaruh Gaya Kepemimpinan terhadap Komitmen Organisasi}

Gaya kepemimpinan merupakan pola-pola perilaku konsisten yang diterapkan pemimpin dengan dan melalui orang lain pada saat mempengaruhi orang lain (Hersey \& Blanchard, 1984 dalam Mustikawati, 2006). Penelitian yang dilakukan oleh Tatlah et al. (2011) mengenai pengaruh antara gaya kepemimpinan terhadap komitmen organisasi yang menggunakan sampel sekolah menunjukkan bahwa perilaku kepemimpinan memiliki pengaruh yang signifikan terhadap komitmen organisasi. Penelitian yang dilakukan oleh Koesmono (2007) mengenai pengaruh kepemimpinan dan tuntutan tugas terhadap komitmen organisasi dengan variabel moderasi motivasi perawat yang menggunakan sampel rumah sakit swasta di Surabaya menunjukkan bahwa kepemimpinan berpengaruh terhadap komitmen organisasi.

Selain itu penelitian yang dilakukan oleh Sabir et al. (2011) mengenai pengaruh gaya kepemimpinan terhadap komitmen organisasi yang menggunakan sampel pendidikan profesi di Pakistan menunjukkan bahwa gaya kepemimpinan berpengaruh signifikan terhadap komitmen organisasi. Gaya kepemimpinan yang menimbulkan kenyamanan bagi karyawan dapat berpengaruh terhadap komitmen karyawan. Oleh karena itu hipotesis dalam penelitian ini dapat dirumuskan sebagai berikut:

$\mathbf{H}_{3}$ : Gaya kepemimpinan berpengaruh terhadap komitmen organisasi.

\section{METODE PENELITIAN}

\section{Pengumpulan Data}

Responden dalam penelitian ini adalah karyawan, karena mereka yang dapat menilai variabel partisipasi anggaran, keadilan prosedural, dan gaya kepemimpinan dengan baik berdasarkan pengalaman sehari-hari mereka selama bekerja. Penelitian ini dibatasi dengan karyawan yang bekerja di Rumah Sakit dan Klinik di wilayah Tangerang Selatan. Metode pemilihan sampel dilakukan dengan simple random sampling. 


\section{Definisi Operasional dan Pengukuran Variabel}

Operasionalisasi dari masing-masing variabel yang ada di dalam penelitian ini dijelaskan di dalam tabel 1 di bawah ini:

Tabel 1. Operasionalisasi Variabel Penelitian

\begin{tabular}{|c|c|}
\hline Variabel & $\begin{array}{l}\text { Indikator } \\
\end{array}$ \\
\hline \multirow{5}{*}{$\begin{array}{l}\text { Partisipasi } \\
\text { Penganggaran } \\
\left(\mathrm{X}_{1}\right) \\
(\text { Milani, 1975) }\end{array}$} & 1. Keikutsertaan dalam penyusunan anggaran \\
\hline & $\begin{array}{l}\text { 2. Menyatakan pendapat dan atau usulan tentang anggaran } \\
\text { kepada atasan, tanpa diminta }\end{array}$ \\
\hline & $\begin{array}{l}\text { 3. Besarnya pengaruh bawahan yang tercermin dalam } \\
\text { anggaran akhir }\end{array}$ \\
\hline & $\begin{array}{l}\text { 4. Seberapa penting usulan atau pemikiran terhadap proses } \\
\text { penyusunan anggaran }\end{array}$ \\
\hline & $\begin{array}{l}\text { 5. Seberapa sering atasan meminta pendapat dan atau usulan } \\
\text { kepada bawahan ketika anggaran sedang disusun }\end{array}$ \\
\hline \multirow{4}{*}{$\begin{array}{l}\text { Keadilan } \\
\text { Prosedural }\left(\mathrm{X}_{2}\right) \\
\text { (McFarlin dan } \\
\text { Sweeney, 1992) }\end{array}$} & $\begin{array}{l}\text { 1. Mengetahui seberapa adil prosedur yang digunakan oleh } \\
\text { organisasi untuk mengevaluasi kinerja karyawan }\end{array}$ \\
\hline & $\begin{array}{l}\text { 2. Mengetahui seberapa adil prosedur yang digunakan oleh } \\
\text { organisasi untuk menentukan promosi (jabatan) }\end{array}$ \\
\hline & $\begin{array}{l}\text { 3engetahui seberapa adil prosedur yang digunakan oleh } \\
\text { organisasi untuk mengkomunikasikan umpan balik tentang } \\
\text { kinerja }\end{array}$ \\
\hline & $\begin{array}{l}\text { 4. Mengetahui seberapa adil prosedur yang digunakan oleh } \\
\text { organisasi untuk menentukan kenaikan gaji }\end{array}$ \\
\hline \multirow{12}{*}{$\begin{array}{l}\text { Gaya } \\
\text { Kepemimpinan } \\
\left(\mathrm{X}_{3}\right) \\
\text { (Fiedler dan } \\
\text { Yuki, 1981) }\end{array}$} & 1. Sikap yang menyenangkan \\
\hline & 2. Bersahabat \\
\hline & 3. Menerima pendapat orang lain \\
\hline & 4. Sikap rileks \\
\hline & 5. Kedekatan dengan para karyawan \\
\hline & 6. Mendukung karyawan \\
\hline & 7. Sikap harmonis \\
\hline & 8. Sikap periang, terbuka, loyal \\
\hline & 9. Dapat dipercaya \\
\hline & 10. Keramahan terhadap karyawan \\
\hline & 11. Kooperatif \\
\hline & 12. Sikap jujur dan baik \\
\hline \multirow{9}{*}{$\begin{array}{l}\text { Komitmen } \\
\text { Organisasi (Y) } \\
\text { (Mowday et al., } \\
\text { 1979) }\end{array}$} & 1. Membantu kesuksesan organisasi \\
\hline & 2. Kebanggaan terhadap organisasi \\
\hline & 3. Kesediaan menerima semua tipe tugas \\
\hline & $\begin{array}{l}\text { 4. Merasa nilai yang ingin dicapai serupa dengan nilai-nilai } \\
\text { organisasi }\end{array}$ \\
\hline & 5. Merasa bangga menjadi bagian dari organisasi \\
\hline & $\begin{array}{l}\text { 6. Merasa organisasi menjadi inspirasi untuk melaksanakan } \\
\text { tugas dengan baik }\end{array}$ \\
\hline & 7. Merasa senang bergabung dalam organisasi \\
\hline & 8. Merasa bahwa organisasi ini merupakan organisasi terbaik \\
\hline & 9. Memperhatikan nasib organisasi \\
\hline
\end{tabular}




\section{Teknik Analisis Data}

Kuesioner yang digunakan di dalam penelitian ini sudah memenuhi uji kualitas data, yaitu uji validitas dan reliabilitas dan uji asumsi klasik, yaitu uji normalitas data, uji multikolinieritas, dan uji heteroskedastisitas.

Uji hipotesis pada penelitian ini menggunakan analisis regresi berganda. Menurut Ghozali (2011), analisis regresi berganda bertujuan untuk mengukur kekuatan hubungan antara dua variabel atau lebih (variabel independen terhadap variabel dependen). Persamaan regresi berganda dirumuskan:

Keterangan:

$$
\mathbf{Y}=\mathbf{a}+\mathbf{b}_{1} \mathbf{X}_{1}+\mathbf{b}_{2} \mathbf{X}_{2}+\mathbf{b}_{3} \mathbf{X}_{3}+\mathbf{e}
$$

$$
\begin{aligned}
& \mathrm{Y}=\text { Komitmen Organisasi } \\
& \mathrm{a}=\text { Konstanta } \\
& \mathrm{b}=\text { Koefisien Regresi } \\
& \mathrm{X}_{1}=\text { Partisipasi Penganggaran } \\
& \mathrm{X}_{2}=\text { Keadilan Prosedural } \\
& \mathrm{X}_{3}=\text { Gaya Kepemimpinan } \\
& \mathrm{e}=\text { Eror }
\end{aligned}
$$

\section{ANALISIS HASIL PENELITIAN}

\section{Deskripsi Umum Sampel}

Penelitian ini dilakukan terhadap karyawan yang bekerja di beberapa Rumah Sakit dan klinik yang berada di wilayah Tangerang Selatan dan sekitarnya. Karyawan yang berpartisipasi dalam penelitian ini meliputi perawat, dokter, fisioterapis, bidan, staf divisi, apoteker, analis, administrasi, asisten apoteker, dan kasir yang melaksanakan pekerjaan di bidang pelayanan Rumah Sakit.

Peneliti mengambil sampel sebanyak 4 (empat) Rumah Sakit dan dua klinik dari keseluruhan Rumah Sakit dan klinik yang berada di wilayah Tangerang Selatan dan sekitarnya. Kuesioner yang disebarkan berjumlah 125 buah dan jumlah kuesioner yang kembali adalah sebanyak 110 kuesioner atau 88\%. Kuesioner yang tidak kembali sebanyak 15 buah atau 12\%, hal ini mungkin dikarenakan kesibukan kerja karyawan Rumah Sakit dan klinik. Kuesioner yang dapat diolah berjumlah 109 buah atau 87,2\%, sedangkan kuesioner yang tidak dapat diolah karena tidak memenuhi kriteria sebagai sampel dan tidak diisi secara lengkap oleh responden sebanyak 1 buah atau o, $8 \%$.

\section{Pengujian Hipotesis}

Hasil pengujian regresi berganda disajikan pada tabel berikut:

Tabel 2. Hasil Uji Statistik t

\begin{tabular}{|l|c|c|c|c|c|}
\hline \multirow{2}{*}{ Model } & \multicolumn{2}{|c|}{$\begin{array}{c}\text { Unstandardized } \\
\text { Coefficients }\end{array}$} & $\begin{array}{c}\text { Standardized } \\
\text { Coefficients }\end{array}$ & \multirow{2}{*}{$\mathrm{t}$} & \multirow{2}{*}{ Sig. } \\
\cline { 2 - 5 } & $\mathrm{B}$ & $\begin{array}{c}\text { Std. } \\
\text { Error }\end{array}$ & Beta & & \\
\cline { 2 - 5 } & 13,849 & 2,880 & & 4,809 & 0,000 \\
\hline $\begin{array}{l}\text { Partisipasi } \\
\text { Penganggaran }\end{array}$ & 0,231 & 0,110 & 0,181 & 2,106 & 0,038 \\
\hline Keadilan Prosedural & 0,360 & 0,142 & 0,241 & 2,540 & 0,013 \\
\hline Gaya Kepemimpinan & 0,158 & 0,288 & 0,288 & 3,100 & 0,002 \\
\hline
\end{tabular}




\section{Dependent Variable: Komitmen Organisasi}

Berdasarkan tabel 2 di atas, dapat dilihat bahwa partisipasi penganggaran memiliki pengaruh terhadap komitmen organisasi dengan nilai signifikansi sebesar o,038 (di bawah 0,05). Partisipasi penganggaran dapat menimbulkan kepercayaan diri para karyawan karena merasa dibutuhkan dalam suatu organisasi, sehingga mereka merasa memiliki organisasi tersebut dan memberikan masukan bagi kemajuan organisasi, dalam hal ini mengenai anggaran yang dibutuhkan organisasi, serta mendedikasikan diri mereka secara maksimal dalam kegiatan organisasi. Dengan merasa memiliki organisasi, secara otomatis dapat meningkatkan komitmen organisasi. Dari hasil uji tersebut dapat disimpulkan bahwa $\mathrm{H}_{1}$ diterima. Penelitian ini mendukung penelitian yang dilakukan oleh Abbas (2008) dan Yunita (2009) yang menyatakan bahwa partisipasi penganggaran mempunyai pengaruh yang signifikan terhadap komitmen organisasi.

Tabel 2 juga memperlihatkan nilai variabel keadilan prosedural sebesar 0,013 yang berarti keadilan prosedural memiliki pengaruh terhadap komitmen organisasi. Keadilan prosedural berhubungan dengan persepsi bawahan mengenai seluruh proses yang diterapkan oleh atasan mereka untuk mengevaluasi kinerja mereka untuk mengkomunikasikan feedback kinerja dan untuk menentukan reward bagi mereka seperti promosi atau kenaikan gaji. Karyawan yang merasa bahwa prosedur dalam organisasi mereka telah diterapkan secara adil akan merasa dihargai sehingga meningkatkan komitmen organisasi pada diri mereka. Berdasarkan hal tersebut dapat disimpulkan bahwa $\mathrm{H}_{2}$ diterima. Penelitian ini mendukung penelitian Bakhshi et al. (2009) yang menyatakan bahwa keadilan prosedural memiliki hubungan yang signifikan terhadap komitmen organisasi.

Selain itu, gaya kepemimpinan memiliki nilai signifikansi sebesar 0,002 yang menunjukkan bahwa gaya kepemimpinan memiliki pengaruh terhadap komitmen organisasi. Gaya kepemimpinan yang baik akan membawa rasa nyaman bagi para karyawannya untuk bekerja sehingga mereka memiliki keinginan untuk menetap dalam organisasi tersebut. Dengan begitu komitmen organisasi akan tercipta dan dapat meningkat dengan gaya kepemimpinan yang baik. Berdasarkan hal tersebut dapat disimpulkan bahwa $\mathrm{H}_{3}$ diterima. Hasil penelitian ini konsisten dengan hasil penelitian yang dilakukan oleh Koesmono (2007), Tatlah et al. (2011), dan Sabir et al. (2011) yang menyatakan bahwa gaya kepemimpinan memiliki pengaruh yang signifikan terhadap komitmen organisasi.

\section{SIMPULAN}

Penelitian ini bertujuan untuk mengetahui pengaruh Partisipasi Penganggaran, Keadilan Prosedural, dan Gaya Kepemimpinan terhadap Komitmen Organisasi. Berdasarkan pada data yang telah dikumpulkan dan hasil pengujian yang telah dilakukan terhadap permasalahan dengan menggunakan analisis regresi, maka dapat diambil kesimpulan sebagai berikut:

1. Partisipasi penganggaran memiliki pengaruh terhadap komitmen organisasi. Hasil penelitian ini konsisten dengan penelitian yang dilakukan oleh Abbas (2008) dan Yunita (2009) yang menyatakan bahwa partisipasi penganggaran memiliki pegaruh terhadap komitmen organisasi.

2. Keadilan prosedural memiliki pengaruh terhadap komitmen organisasi. Hasil penelitian ini konsisten dengan penelitian yang dilakukan oleh Bakhshi et al. (2009) yang menyatakan bahwa keadilan prosedural memiliki pengaruh terhadap komitmen organisasi.

3. Gaya kepemimpinan memiliki pengaruh terhadap komitmen organisasi. Hasil penelitian ini konsisten dengan penelitian yang dilakukan oleh Koesmono (2007), 
Tatlah et al. (2011), dan Sabir et al. (2011) yang menyatakan bahwa gaya kepemimpinan memiliki pengaruh terhadap komitmen organisasi.

Penelitian ini di masa mendatang diharapkan dapat menyajikan hasil penelitian yang lebih berkualitas lagi dengan adanya beberapa masukan mengenai beberapa hal diantaranya:

1. Untuk penelitian selanjutnya disarankan untuk menambah variabel lain berpengaruh terhadap komitmen organisasi.

2. Penelitian selanjutnya disarankan untuk menggunakan metode gabungan antara evaluasi bawahan terhadap atasan dan evaluasi atasan terhadap bawahannya, agar hasil penelitian yang dilakukan bisa digeneralisasi dalam upaya memberikan dukungan empiris terhadap teori yang diajukan.

3. Penelitian lebih lanjut diharapkan dapat memperluas daerah survei atau menggunakan sampel yang berbeda dari penelitian ini, sehingga hasil penelitian lebih mungkin untuk disimpulkan secara umum.

\section{PUSTAKA ACUAN}

Abbas, Syafruddin. 2008. "Pengaruh Penganggaran Partisipatif Terhadap Komitmen Organisasi, Job-Relevant Information dan Kinerja Manajerial”, Jurnal Megadigma Vol. 2 No. 2.

Amilin dan Rosita Dewi. 2008. "Pengaruh Komitmen Organisasi Terhadap Kepuasan Kerja Akuntan Publik Dengan Role Stress Sebagai Variabel Moderating”, Jurnal Akuntansi $\mathcal{E}$ Auditing Indonesia, Vol. 12 No. 1 Juni Hal 13-24, Fakultas Ekonomi dan Ilmu Sosial UIN Syarif Hidayatullah Jakarta.

Anthony, Robert N., dan Vijay Govindarajan. 2009. "Management Control System", Edisi 11, Buku 1, Salemba Empat, Jakarta.

Bakhshi, Arti, Kuldeep Kumar, dan Ekta Rani. 2009. “Organizational Justice Perceptions As Predictor Of Job Satisfaction And Organization Commitment", International Journal of Business and Management, Vol. 4 No. 9.

Dharmanegara, Ida Bagus Agung. 2010. "Penganggaran Perusahaan Teori dan Aplikasi", Graha Ilmu, Yogyakarta.

Falikhatun. 2007. "Interaksi Informasi Asimetri, Budaya Organisasi, dan Group Cohesiveness Dalam Hubungan Antara Partisipasi Penganggaran dan Budgetary Slack", Simposium Nasioanal Akuntansi X, Makassar.

Fitri, Yulia. 2004. "Pengaruh Informasi Asimetris, Partisipasi Penganggaran dan Komitmen Organisasi Terhadap Timbulnya Senjangan Anggaran”, Simposium Nasional Akuntansi VII, Denpasar.

Ghozali, Imam. 2011. "Aplikasi Analisis Multivariate dengan program IBM SPSS 19”, Edisi 5, Badan Penerbit Universitas Diponegoro, Semarang.

Hansen, Don R., dan Maryanne M. Mowen. 2009. "Akuntansi Manajerial”, Edisi 8, Buku 1, Salemba Empat, Jakarta.

Hartanto, Frans Mardi. 2009. "Paradigma Baru Manajemen Indonesia: Menciptakan Nilai Dengan Bertumpu Pada Kebijakan dan Potensi Insani”, PT. Mizan Pustaka, Bandung.

Horngren, Charles T., Srikant M. Datar, dan George Foster. 20o8. "Akuntansi Biaya: Penekanan Manajerial", Jilid 1, PT. Indeks, Jakarta.

Ikhsan, Arfan dan La Ane. 2007. "Pengaruh Partisipasi Anggaran Terhadap Senjangan Anggaran Dengan Menggunakan Lima Variabel Pemoderasi”, Simposium Nasional Akuntansi X, Makasar. 
Ivancevich, John M., Robert Konopaske, dan Michael T. Matteson. 2007. "Perilaku dan Manajemen Organisasi”, Edisi 7, Jilid 1, Penerbit Erlangga, Jakarta.

Kartono, Kartini. 1998. "Pemimpin Dan Kepemimpinan: Apakah Kepemimpinan Abnormal Itu?”, PT. Raja Grafindo Persada, Jakarta.

Kim, Hyo-Sook. "Integrating Organizarional Justice Into the Relationship Management Theroy: The Influence of Organizational Justice on Employee-Organization Relationships", 2009. Jurnal diakses pada tanggal 5 Mei 2012, dari http://www.allacademic.com.

Koesmono, H. Teman. 2007. "Pengaruh Kepemimpinan dan Tuntutan Tugas Terhadap Komitemen Organisasi dengan Variabel Moderasi Motivasi Perawat Rumah Sakit Swasta Surabaya", Jurnal manajemen dan kewirausahaan Universitas Kristen Petra Surabaya Vol. 9 No. 1 Hal. 30-40.

Kreitner, Robert dan Angelo Kinicki. 2005. "Perilaku Organisasi”, Jilid 2, Salemba Empat, Jakarta.

Maisyarah, Renny. 2008. "Pengaruh Partisipasi Penyusunan Anggaran Terhadap Kinerja Manajerial dengan Komunikasi dan Komitmen sebagai Variabel Moderating Pada PDAM Propinsi Sumatera Utara". Tesis, Universitas Sumatera Utara.

Mustikawati, $\mathrm{Rr}$ Indah. 20o6. "Pengaruh Goal Orientation dan Gaya Kepemimpinan Terhadap Peran Akuntan Manajemen dalam Pengambilan Keputusan Bisnis dan Adopsi Teknik Akuntansi Manajemen Baru”, Simposium Nasional Akuntansi IX, Padang.

Nafarin, M. 2007. “Penganggaran Perusahaan”, Edisi 3, Salemba Empat, Jakarta.

Nor, Wahyudin. 2007. "Desentralisasi dan Gaya Kepemimpinan sebagai Variabel Moderating dalam Hubungan antara Partisipasi Penyusunan Anggaran dan Kinerja Manajerial", Simposium Nasional Akuntansi X, Makassar.

Puspaningsih, Abriyani. 2002. "Pengaruh Partisipasi Anggaran dalam Penyusunan Anggaran Terhadap Kepuasan Kerja dan Kinerja Manajerial”, JAAI Vol. 6 No. 2, Desember.

Robbins, Stephen P., dan Timothy A. Judge. 2008. "Organizational Behavior", Edisi 12, Salemba Empat, Jakarta.

Sabir, M. Suleman, Adil Sohail, dan Muhammad Asif Khan. 2011. "Impact of Leadership Style on Organization Commitment: In A Mediating Role of Employee Values", Journal of Economics and Behavioral Studies, Vol. 3 No. 2.

Sardjito, Bambang dan Osmad Muthaher. 2007. "Pengaruh Partisipasi Penyusunan Anggaran Terhadap Kinerja Aparat Pemerintah Daerah: Budaya Organisasi dan Komitmen Organisasi Sebagai Variabel Moderating", Simposium Nasional Akuntansi X, Makassar.

Sumarno, J. 2005. "Pengaruh Komitmen Organisasi Dan Gaya Kepemimpinan Terhadap Hubungan Antara Partisipasi Anggaran Dan Kinerja Manajerial”, Simposium Nasional Akuntansi VIII, Solo.

Sopiah. 2008. "Perilaku Organisasi”, Andi Yogyakarta, Yogyakarta.

Syam, Fazli BZ., dan Muslim A Djalil. 2006."Pengaruh Orientasi Profesional Terhadap Konflik Peran: Interaksi antar Partisipasi Anggaran dan Penggunaan Anggaran Sebagai Alat Ukur Kinerja Dengan Orientasi Manajerial”, Simposium Nasional Akuntansi IX, Padang.

Tatlah, Ahmad Ijaz, Zulfikar Ali, dan Muhammad Saeed. 2011. "Leadership Behavior and Organizational Commitment: An Empirical Study of Edicational Professionals", International Journal of Academic Research, Vol. 3 No. 2.

Usman, Husaini. 2010. "Manajemen: Teori, Praktik, dan Riset Pendidikan", Edisi 3, Bumi Aksara, Jakarta. 
Wasisto, Arief dan Mahfud Sholihin. 2004. "Peran Partisipasi Penganggaran Dalam Hubungan Antara Keadilan Prosedural Dengan Kinerja Manajerial dan Kepuasan Kerja”, Simposium Nasional Akuntansi VII, Denpasar.

Yanti, Firmani Indah. 2008. "Analisa Pengaruh Partisipasi Anggaran Terhadap Senjangan Anggaran Dengan Komitmen Organisasi Sebagai Variabel Moderating”, Skripsi Fakultas Ekonomi dan Ilmu Sosial, Universitas Islam Negeri Syarif Hidayatullah, Jakarta.

Yaverbaum, E. dan Sherman, E. 2008. "Everthing Leadership Book”, Second Edition, Adams Media: Avon, Massachusetts.

Yuniarti dan Saty. 2008. "Pengaruh Komitmen Organisasi dan Gaya Kepemimpinan Antara Partisipasi Anggaran dan Kinerja Manajerial (Studi Empiris Pada Kantor Cabang Perbankan di Propinsi Lampung)", Jurnal Ilmiah ESAI. 